\title{
IMPLEMENTASI MANAJEMEN PERPUSTAKAAN DALAM MENINGKATKAN MINAT BACA PESERTA DIDIK DI MADRASAH TSANAWIYAH NEGERI GOWA
}

\author{
UMMUL FADHILAH', MULJONO DAMOPOLII ${ }^{2}$, M. YUSUF TAHIR ${ }^{3}$ \\ 1,2,3Universitas Islam Negeri Alauddin Makassar \\ Email:1 1fadhilahu941@gmail.com,2muljono.damopolii@uin-alauddin.ac.id, 3yusuftahir@uin- \\ alauddin.ac.id
}

\begin{abstract}
Implementation of Library Management in Increasing Students' Reading Interest in Madrasah Tsanawiyah Negeri Gowa

This study aims to: determine the reality of the library, a description of students' reading interest, and the implementation of library management in increasing students' reading interest in Madrasah Tsanawiyah Negeri Gowa. This type of research is a collaborative action research school (madrasah) using a management approach. This research is located in Madrasah Tsanawiyah Negeri Gowa. Data collection uses two types of data, namely primary data sources through direct observation and observation and secondary data sources from books, journals, and other important documents. The results of this study indicate that the implementation of library management can increase students' reading interest in Madrasah Tsanawiyah Negeri Gowa. This can be seen from the increasing number of library visitors each cycle, namely in cycle 1 as many as 24 people (5.15\%), cycle II as many as 69 people (14.81\%), and cycle III as many as 151 people (32.40\%) of the total number of students as many as 466 people. Based on these calculations, cycle 1 to cycle II has increased by $9.66 \%$ while from cycle II to cycle III has increased by 17.59\%. Thus the interest of students in Madrasah Tsanawiyah Negeri Gowa has increased. The implication of this research is that the head of the madrasa should provide adequate facilities and infrastructure in the library so that students feel happy and interested in entering the library. Meanwhile, the library must further improve good library management in carrying out work programs prepared by making SOP so that the implementation of each program can run effectively and efficiently.
\end{abstract}

Keywords: Management, Library, Library Management, Reading Interest

\section{Abstrak: Implementasi Manajemen Perpustakaan dalam Meningkatkan Minat Baca Peserta Didik di Madrasah Tsanawiyah Negeri Gowa}

Penelitian ini bertujuan untuk: mengetahui realitas manajemen perpustakaan, gambaran minat baca peserta didik, dan implementasi manajemen perpustakaan dalam meningkatkan minat baca peserta didik di Madrasah Tsanawiyah Negeri Gowa. Jenis penelitian ini merupakan kolaborasi penelitian tindakan sekolah (madrasah) dengan menggunakan pendekatan manajemen. Penelitian ini berlokasi di Madrasah Tsanawiyah Negeri Gowa. Pengambilan data menggunakan dua jenis data yaitu sumber data primer dilakukan melalui observasi dan pengamatan secara langsung dan sumber data sekunder diambil 
dari buku, jurnal, serta dokumen penting lainnya. Hasil penelitian ini menunjukkan bahwa dengan implementasi manajemen perpustakaan dapat meningkatkan minat baca peserta didik di Madrasah Tsanawiyah Negeri Gowa. Hal ini dapat dilihat dari jumlah pengunjung perpustakaan yang semakin meningkat di setiap siklusnya yaitu pada siklus 1 sebanyak 24 orang $(5,15 \%)$, siklus II sebanyak 69 orang (14,81\%), dan siklus III sebanyak 151 orang $(32,40 \%)$ dari jumlah total peserta didik sebanyak 466 orang. Berdasarkan perhitungan tersebut, siklus 1 ke siklus II mengalami peningkatan sebesar 9,66\% sedangkan dari siklus II ke siklus III mengalami peningkatan sebesar 17,59\%. Dengan demikian minat baca peserta didik di Madrasah Tsanawiyah Negeri Gowa mengalami peningkatan. Implikasi dari penelitian ini yaitu kepala madrasah sebaiknya menyediakan sarana dan prasarana yang memadai di perpustakaan agar peserta didik merasa senang dan tertarik untuk masuk perpustakaan. sementara itu, pihak perpustakaan harus meningkatkan lagi manajemen perpustakaan yang baik dalam melaksanakan program kerja yang telah disusun dengan membuat SOP agar pelaksanaan setiap program kerja bisa berjalan dengan efektif dan efisien.

Kata Kunci: Manajemen, Perpustakaan, Manajemen Perpustakaan, Minat Baca

\section{PENDAHULUAN}

Manusia diciptakan sebagai makhluk yang sempurna dan diberi berbagai potensi oleh Allah swt. Mengingat begitu besar dan berharganya potensi yang dimiliki manusia, maka manusia harus dibekali dengan pendidikan. Pendidikan adalah usaha paling efektif untuk membentuk karakter seseorang. Penyelenggaraan dan proses pendidikan pada semua jenjang pendidikan ditentukan oleh faktor pendidik dan faktor penunjang lainnya (Getteng, 2014). Satuan pendidikan atau sekolah pada semua jenjang dan jenis dihadapkan pada persaingan mutu yang ketat dan manajemen sekolah yang kompleks, sehingga pemahaman yang akurat tentang tujuan serta metode oleh setiap Kepala Sekolah untuk mencapai tujuan adalah amat vital. Untuk mencapai tujuan tersebut di setiap sekolah telah menyediakan berbagai fasilitas belajar, salah satu diantaranya adalah perpustakaan sekolah. Perpustakaan sekolah adalah perpustakaan yang ada di sekolah sebagai sarana pendidikan untuk menunjang pencapaian tujuan pendidikan prasekolah, pendidikan dasar, dan pendidikan menengah (Sagala, 2014).

Perpustakaan sekolah adalah unit kerja yang melakukan kegiatan/fungsi pengadaan, pengolahan, penyimpanan, dan pendayagunaan serta pemeliharaan atau pelestarian koleksi bahan pustaka untuk mendukung proses pembelajaran. Perpustakaan sekolah sebagai salah satu komponen dalam sistem pendidikan nasional mengemban fungsi sebagai pusat kegiatan pembelajaran, pusat penelitian sederhana, dan pusat membaca guna menambah ilmu pengetahuan, perlu terus- 
menerus dibina dan dikembangkan. Perpustakaan sangat penting karena ia merupakan jembatan peradaban bangsa, tempat memancarkan ilmu pengetahuan, dan sebagai wahana meningkatkan mutu pendidikan dan daya saing bangsa. Perpustakaan harus menyediakan dan mengelola berbagai bahan perpustakaan sebagai sumber literatur yang berhubungan dengan pendidikan dan proses pembelajaran sehingga dapat berfungsi sebagai tempat dan sumber belajar bagi siswa. Penyelenggara perpustakaan bukan hanya sebatas untuk mengumpulkan dan menyimpan bahan-bahan pustaka, melainkan juga membantu para siswa dalam mendapatkan bahan-bahan pelajaran yang diinginkan. Sementara bagi guru, perpustakaan menjadi sumber referensi utama untuk memperoleh materi-materi pelajaran (Hartono, 2016). Sebagaimana dalam firman Allah swt. dalam QS alSaff/61:4.

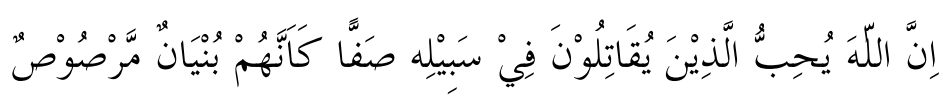

"Sesungguhnya Allah mencintai orang-orang yang berperang di jalan-Nya dalam barisan yang teratur, mereka seakan-akan seperti suatu bangunan yang tersusun kokoh" (Departemen Agama RI, 2012).

Maksud dari ayat di atas diharapkan ada sinergi yang rapi antara bagian satu dengan bagian yang lain agar memperoleh hasil yang maksimal. Maka dari itu eksistensi perpustakaan sekolah dalam proses belajar mengajar harus dapat mengarahkan keterampilan siswa dalam hal pembinaan minat siswa agar siswa dapat menjadi mandiri dalam mencari ilmu pengetahuan (Yeni, 2020).

Perpustakaan memiliki kedudukan strategis dalam mengembangkan dan meningkatkan minat baca siswa. Siswa dapat melakukan proses pendidikan nonformal melalui fasilitas yang disediakan dan kegiatan yang diselenggarakan oleh perpustakaan. Keberadaan sumber belajar di tengah-tengah masyarakat ini diharapkan mampu mendorong dan mempercepat terwujudnya masyarakat pembelajar (learning society). Yakni masyarakat yang gemar membaca dan mampu meningkatkan daya saing di era kompetitif ini (Kalida, 2015).

Perpustakaan dan minat baca, keduanya memiliki ketergantungan bagaikan mata uang logam, mereka adalah kedua sisinya. Seperti yang dikatakan Supriyanto, pustakawan utama Perpustakaan Nasional RI dalam tulisannya, bahwa misi utama perpustakaan adalah menyediakan layanan dan pemberdayaan koleksi pustaka. Terlaksananya misi tersebut amat tergantung pada kondisi perkembangan minat dan kebiasaan membaca, tetapi sebaliknya minat dan kebiasaan membaca hanya memadai, cukup, sesuai, menarik untuk dibaca, dan mudah diperoleh bagi pemustaka (Juni, 2016).

Salah satu upaya untuk meningkatkan kualitas sumber daya manusia adalah pengembangan minat baca dan kebiasaan membaca, perpustakaan diharapkan sebagai pusat kegiatan pengembangan minat baca dan kebiasaan membaca, 
sehingga semakin disadari bahwa masyarakat gemar membaca merupakan persyaratan dalam mewujudkan masyarakat gemar membaca yang merupakan salah satu ciri masyarakat maju dan beradab (Suwarno, 2011). Oleh karena itu, guru sebagai teladan harus memberikan contoh kepada peserta didiknya. Danial \& Damopolii (2019) menyatakan bahwa Guru merupakan faktor yang paling dominan dan paling penting dalam pendidikan formal karena bagi peserta didik, guru selalu dijadikan sebagai teladan dan bahkan menjadi tokoh identifikasi diri. Hal ini menunjukkan bahwa guru merupakan salah satu unsur yang dapat membantu peserta didik dalam meningkatkan minat baca. Rahman (2021) mengemukakan bahwa pendidikan pada dasarnya merupakan suatu proses komunikasi informasi dari pendidik kepada peserta didik yang berisi informasiinformasi pendidikan, yang memiliki unsur pendidik sebagai sumber informasi, media sebagai sarana penyajian ide, gagasan dan materi pendidikan serta peserta didik itu sendiri.

Kegiatan membaca sudah semestinya merupakan aktivitas rutin sehari-hari bagi masyarakat untuk memperoleh pengetahuan dan informasi. Di dalam dunia pendidikan, membaca mempunyai fungsi sosial untuk memperoleh kualifikasi tertentu sehingga seseorang dapat mencapai prestasi. Seorang peserta didik yang ingin memperoleh kelulusan dengan baik, maka ia harus membaca sejumlah bahan bacaan yang direkomendasikan oleh pendidik. Demikian pula bagi seorang pendidik, untuk meraih kualifikasi tertentu dalam mengajar ataupun menulis karya ilmiah, maka ia harus didukung dengan kegiatan membaca berbagai bahan bacaan untuk selalu memperbarui pengetahuannya secara kontinu sesuai dengan perkembangan yang ada. Sebagaimana dalam firman Allah swt. dalam QS al'Alaq/96:3.

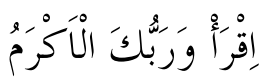

"Bacalah, dan Tuhanmulah yang maha mulia" (Depatemen Agama RI, 2012)

Ayat ini menunjukkan adanya perintah membaca. Membaca adalah sarana untuk belajar dan kunci ilmu pengetahuan, baik secara etimologis berupa membaca huruf-huruf yang tertulis dalam buku-buku, maupun terminologis, yakni membaca dalam arti lebih luas. Ayat al-Qur'an yang pertama diturunkan menunjuk pada ilmu pengetahuan, yaitu dengan memerintahkan membaca sebagai kunci ilmu pengetahuan (Lubis, 2019).

Indonesia merupakan salah satu negara berkembang dengan minat baca masyarakatnya yang masih rendah. Situasi tersebut dapat dilihat dari beberapa hasil survei. Di antaranya survei yang dilakukan oleh organisasi pendidikan, ilmu pengetahuan dan kebudayaan PBB (UNESCO) 2019, Indonesia menduduki 60 dari 61 negara di dunia pada level literasi baca. Menurut data UNESCO, minat baca 
peserta didik di Indonesia sangat memprihatinkan yaitu 0,001\% yang artinya hanya ada 1 dari 1.000 orang penduduk Indonesia yang memiliki minat baca tinggi. Selain itu, survei tersebut mengungkapkan bahwa anak-anak Indonesia hanya mampu membaca 27 halaman buku per tahun atau dengan kata lain, anak-anak usia sekolah di Indonesia hanya mampu membaca 1 halaman buku selama 15 hari. Berbagai upaya telah dilakukan guna meningkatkan minat baca masyarakat. Namun, Indonesia perlu berusaha lebih keras lagi karena pada era modern ini masyarakat lebih tertarik untuk bermain gadget daripada membaca buku.

Pada kenyataannya, berbagai program yang dilakukan belum memperoleh hasil yang maksimal. Kualitas membaca di Indonesia masih jauh di bawah negaranegara lain. Program for International Student Assesment (PISA) menyebutkan tingkat literasi Indonesia masih berada pada urutan 64 dari 72 negara. Masalah mendasar rendahnya minat dan kebiasaan membaca berhubungan dengan ketersediaan buku, faktor situasional dan pola asuh orang tua (Maharani et al., 2017).

Terdapat berbagai hasil penelitian terkait manajemen perpustakaan dalam meningkatkan minat baca peserta didik. Misalnya, Toha (2015) menunjukkan bahwa ada beberapa upaya yang dilakukan pengelola perpustakaan dalam meningkatkan minat baca peserta didik pada mata pelajaran Pendidikan Agama Islam yaitu, upaya dari segi pemberian pinjaman buku, upaya dari segi pengelolaan ruang perpustakaan, upaya dari segi pengelolaan koleksi buku, dan upaya dalam berinteraksi dengan pihak sekolah. Wahyuningsih (2011) menunjukkan karakteristik peran perpustakaan dalam meningkatkan motivasi belajar siswa adalah petugas dan pustakawan berusaha menjadi fasilitator dan motivator menuju ke arah keberhasilan belajar siswa. Bistara (2016) menunjukkan bahwa kepala sekolah di SMA Kemala Bhayangkari Kota Bumi telah melaksanakan implementasi manajemen perpustakaan dengan cukup baik, terarah dan berkelanjutan. Enyang et al., (2015) menunjukkan bahwa siklus 1 sampai dengan siklus 2 mengalami peningkatan yaitu sebesar 3,23\% pada siklus 3 diperoleh skor $68,93 \%$. Berdasarkan perhitungan tersebut per siklus, siklus 2 sampai dengan siklus 3 mengalami peningkatan. Ahmadi (2010) menunjukkan bahwa Minat belajar siswa dalam mata pelajaran Bahasa Indonesia berbantuan CD pembelajaran glenn doman berbasis multimedia masuk dalam kategori tinggi, yaitu skor rata-ratanya adalah $60 \%$.

Latar belakang yang menjadi permasalahan dilakukannya penelitian ini adalah perpustakaan di Madrasah Tsanawiyah Negeri Gowa belum menerapkan dengan baik proses manajemen perpustakaan dari segi pelaksanaannya. Hal ini terlihat dari pengelolaan ruang perpustakaan dimulai dari penataan rak buku, meja baca, kursi baca, dan dekorasi perpustakaan yang belum tertata secara 
maksimal. Kondisi ruang perpustakaan sangatlah sempit sehingga ketika peserta didik yang datang berkunjung banyak, maka mereka akan berdesak-desakan sehingga menimbulkan rasa kurang nyaman dikarenakan panas dan sulit untuk berkonsentrasi.

Sebagian besar buku-buku yang ada di perpustakaan merupakan koleksi buku lama, jumlah bukunya masih sedikit dan kebanyakan buku fiksi dikarenakan buku-buku pelajaran dipinjamkan ke semua siswa selama 1 tahun. Petugas perpustakaan berjumlah 3 orang dan ada yang bukan sarjana perpustakaan. Menurut kepala perpustakaan mengatakan bahwa:

"Minat baca anak-anak di Madrasah Tsanawiyah Negeri Gowa rendah. Peneliti juga pernah menyurvei daftar pengunjung perpustakaan dan hasilnya dari siswa yang berjumlah 466 hanya ada sekitar 60-an siswa yang berkunjung ke perpustakaan. Jumlah yang paling banyak itu sekitar 90 orang di setiap bulannya. Peserta didik yang datang berkunjung ke perpustakaan tidak semuanya meminjam buku, biasanya yang meminjam buku hanya sekitar 15 orang saja".

Gambaran awal tersebut menjadi fenomena yang menarik sehingga penelitian ini dilakukan untuk mengkaji secara ilmiah tentang "Implementasi Manajemen Perpustakaan dalam Meningkatkan Minat Baca Peserta Didik di Madrasah Tsanawiyah Negeri Gowa". Adapun tujuan penelitian ini, yaitu untuk mengetahui realitas manajemen perpustakaan di Madrasah Tsanawiyah Negeri Gowa, untuk mengetahui gambaran minat baca peserta didik di Madrasah Tsanawiyah Negeri Gowa, dan untuk mendeskripsikan implementasi manajemen perpustakaan dalam meningkatkan minat baca peserta didik di Madrasah Tsanawiyah Negeri Gowa.

\section{METODE PENELITIAN}

Jenis penelitian ini merupakan kolaborasi penelitian tindakan sekolah (madrasah) dengan menggunakan pendekatan manajemen, yaitu metode penelitian yang menekankan pada praktik sosial, bertujuan ke arah peningkatan, suatu proses siklus, diikuti oleh penemuan yang sistematis, proses reflektif, bersifat partisipatif, dan ditentukan oleh pelaksana. Menurut Yaumi \& Damopolii (2014). Kolaborasi penelitian tindakan sekolah (madrasah) terfokus pada isu umum untuk semua tingkat dan rombongan belajar. Keterlibatan dan kontribusi setiap individu dalam seluruh komponen sekolah sangat penting untuk mengkaji sumber masalah dan secara bersama-sama berupaya untuk mengembangkan proses dan membuat komitmen perbaikan satu sama lain. Ketika hambatan itu diatasi, akan ada rasa memiliki dan kebanggaan atas prestasi yang dilakukan dalam kolaborasi penelitian tindakan sekolah (madrasah). 
Penelitian ini dilakukan di Madrasah Tsanawiyah Negeri Gowa, Kabupaten Gowa, Provinsi Sulawesi Selatan. Madrasah Tsanawiyah Negeri Gowa merupakan salah satu pendidikan formal yang terkemuka di Kabupaten Gowa. Pendekatan yang digunakan dalam penelitian ini adalah pendekatan manajemen. Menurut Arsyad (2011), pendekatan manajemen adalah sebuah pendekatan yang bersifat sistematis, karena strategi dan pikiran tercanangkan sebelum melaksanakan penelitian. Penelitian ini menggunakan dua jenis data yaitu data primer dan sumber data sekunder. Penelitian ini dilaksanakan dalam empat tahap, yaitu persiapan, identifikasi ide awal, pencarian dan analisis fakta, pelaksanaan tindakan, serta pengolahan data dan analisis data. Pelaksanaan implementasi terdiri atas siklus. Jumlah siklus yang dilakukan disesuaikan dengan pencapaian tujuan. Maksudnya, apabila tujuan telah tercapai setelah diberi perlakuan maka siklus dihentikan dan penelitian dianggap sudah selesai. Adapun siklus penelitian yang dilakukan dapat dilihat pada Gambar 1.

\section{Gambar 1. Siklus Penelitian Tindakan}

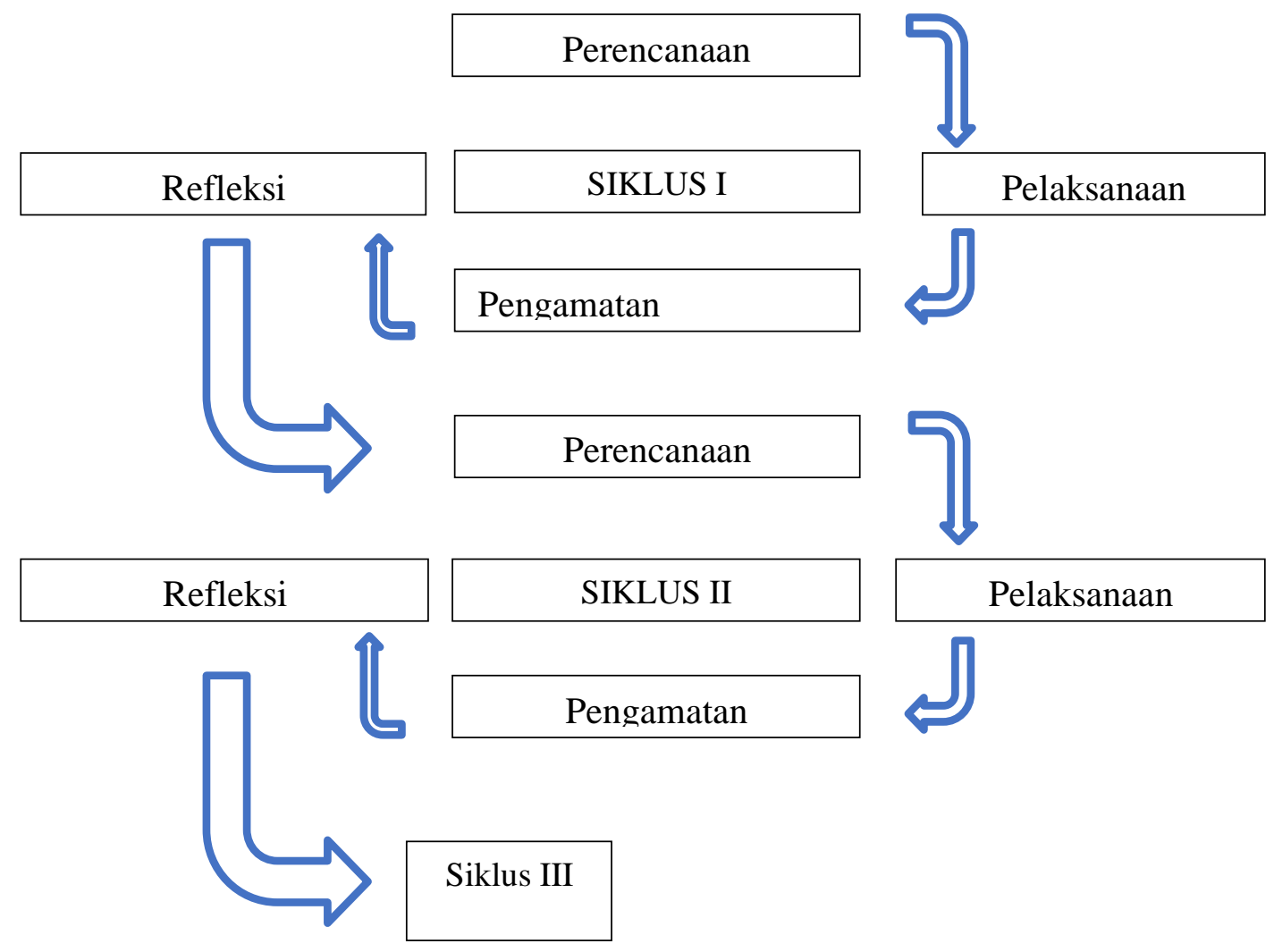

\section{HASIL DAN PEMBAHASAN}

Pada hasil dan pembahasan akan diuraikan tentang gambaran data penelitian yang akan ditampilkan dalam bentuk rangkuman. Dalam hal tersebut akan diuraikan hasil penelitian yang dilanjutkan pembahasan dari hasil tersebut. Hasil yang diperoleh untuk memberikan jawaban terhadap masalah penelitian 
yang dikemukakan dalam siklus penelitian. Penelitian ini dilaksanakan dalam 3 siklus dan hasil dari siklus tersebut akan diuraikan sebagai berikut.

\section{Siklus I}

\section{Perencanaan}

Adapun bentuk perencanaan tindakan yang telah disusun oleh peneliti adalah memperbaharui ruang perpustakaan, membuat mading perpustakaan, membuat teras baca, membuat program wajib baca bekerja sama dengan kepala perpustakaan dan guru bahasa Indonesia, dan mengadakan seminar literasi.

\section{Pelaksanaan}

Pelaksanaan pada tahap penelitian tindakan sekolah pada siklus 1, berlangsung selama 12 hari. Peneliti mulai dari pembaharuan ruang perpustakaan yaitu mengubah tata letak perabot-perabot perpustakaan mulai dari rak buku, meja baca, dan kursi baca. Selain mengatur perabotan-perabotan ruang perpustakaan, peneliti juga mendekorasi ruang perpustakaan agar terlihat lebih indah, karena keindahan dapat membuat perasaan menjadi nyaman dan juga bahagia. Peneliti mulai dari menghias dinding dengan ditempeli sedikit hiasan bunga kertas dan juga menempelkan beberapa kata-kata motivasi terkait akan pentingnya membaca. Kata motivasi ini diharapkan mampu menarik minat dan menumbuhkan semangat peserta didik untuk membiasakan diri membaca buku, karena membaca buku merupakan aktivitas sehari-hari yang mempunyai banyak manfaat.

Setelah itu peneliti lanjut ke pembuatan mading bekerja sama dengan kepala perpustakaan. Peneliti sengaja membuat mading perpustakaan karena sebelumnya perpustakaan tidak mempunyai mading. Selain itu pembuatan mading tidak membutuhkan biaya yang besar. Peneliti menggunakan papan bekas yang telah disiapkan oleh kepala perpustakaan, supaya kelihatan lebih indah peneliti juga menggunakan kain untuk luarannya dan styrofoam untuk bagian dalamnya. Sebelum dibungkus kain papan bekas ini ditempeli styrofoam terlebih dahulu agar supaya lebih memudahkan ketika ingin menempelkan sesuatu. Styrofoam yang digunakan ada dua buah karena ukuran papan agak besar. Setelah styrofoam sudah terpasang dengan rapi selanjutnya dipasanglah kain agar kelihatan lebih indah. Kain yang digunakan adalah kain bekas yang disediakan oleh kepala perpustakaan. Tujuan dari pembuatan mading ini adalah sebagai papan informasi untuk peserta didik agar mengetahui kegiatan-kegiatan perpustakaan dan juga bisa mengetahui program-program perpustakaan yang terbaru. Penempelan foto-foto kegiatan perpustakaan bisa berupa program baru, pelayanan, maupun lomba-lomba yang ada di perpustakaan. Selain itu, mading 
juga bisa digunakan untuk menempelkan kata-kata motivasi akan pentingnya membaca baik itu dari peserta didik maupun pegawai perpustakaan.

Selanjutnya pembuatan teras baca bekerja sama dengan kepala perpustakaan dan petugas perpustakaan lainnya. Membaca buku tidak harus dilakukan di kelas atau perpustakaan saja, tetapi juga bisa dilakukan di teras perpustakaan. Teras yang biasa dipakai untuk duduk santai sambil berkumpul dan bercanda, ternyata juga bisa disulap jadi tempat membaca. Dengan adanya teras baca membuat peserta didik semakin mudah untuk membaca buku, dan teras baca ini bisa digunakan kapan saja seperti membaca di teras sambil menunggu jemputan. Alat-alat yang digunakan dalam pembuatan teras baca ini adalah pipa bekas, tali, cat putih, karpet dan pita. Pipa yang peneliti gunakan sebanyak tiga. Jadi pipa bekas dilubangi terlebih dahulu di bagian tengah sebagai tempat untuk menyimpan buku. Selanjutnya bagian kiri dan kanannya juga diberi lubang tetapi agak kecil kemudian dipasangkan tali yang dipakai untuk menggantung. Ketiga pipa bekas ini peneliti gantung di tembok tepatnya sebelah mading yang menghadap keluar sehingga koleksi bukunya lebih terlihat. Selanjutnya ketiga pipa bekas ini dicat warna putih, agar kelihatan lebih indah dan lebih berwarna.

Selanjutnya adalah peneliti mempublikasikan salah satu program perpustakaan dan program kelas. Salah satu program perpustakaan yang diusulkan oleh peneliti adalah membaca dan meminjam buku di perpustakaan satu kali dalam satu bulan. Peneliti mempublikasikan program ini ke kepala perpustakaan dan juga peneliti ke ruang guru dan menemui guru bidang studi bahasa Indonesia. Selanjutnya peneliti ke mushola dan mempublikasikan langsung ke peserta didik dan memberikan sedikit motivasi tentang pentingnya membaca dan pentingnya program ini. Untuk program kelas sendiri yakni membaca 15 menit sebelum memasuki pelajaran, peneliti bekerja sama dengan guru bidang studi bahasa Indonesia. Jadi setiap ada mata pelajaran bahasa Indonesia peserta didik akan diarahkan untuk ke perpustakaan dulu membaca selama 15 menit sebelum melakukan proses belajar mengajar di kelas.

Program yang terakhir adalah mengadakan seminar literasi (menumbuhkan minat baca dan menulis peserta didik). Salah satu alasan peneliti ingin mengadakan seminar ini adalah agar supaya peserta didik termotivasi untuk menjadikan membaca dan menulis sebagai kebutuhan. Seminar literasi (menumbuhkan minat baca dan menulis peserta didik) ini di adakah di mushola sekolah pada hari Rabu tanggal 11 April 2020, tepatnya jam 14.00. Jumlah peserta didik yang hadir pada seminar ini sekitar 100 orang dan mereka semua adalah anggota OSIS. Peneliti membatasi peserta dikarenakan kondisi mushola yang sempit dan hanya bisa menampung sekitar 100 orang. Waktu seminar pun 
hanya berlangsung 2 jam dikarenakan diantara beberapa peserta didik yang hadir ada yang jarak rumahnya sangat jauh yang menyebabkan guru khawatir jika harus pulang sangat terlambat.

\section{Observasi}

Berdasarkan pengamatan yang dilakukan oleh peneliti didapatkan hasil bahwa jumlah pengunjung perpustakaan di Madrasah Tsanawiyah Negeri Gowa menurun yang menyebabkan minat membaca peserta didik pun menurun. Jumlah peserta didik yang berkunjung setelah diadakan penelitian hanya berjumlah 24 orang, hal ini karena beberapa hari setelah peneliti melakukan penelitian mulai dari pembaharuan ruang perpustakaan, membuat mading, sosialisasi program kelas dan program perpustakaan, membuat teras baca, dan mengadakan seminar literasi, terjadilah pandemi virus corona yang membawa dampak buruk bagi sekolah yang menyebabkan sekolah-sekolah ditutup termasuk Madrasah Tsanawiyah Negeri Gowa. Sekolah ditutup selama tiga bulan dan tidak ada aktivitas sama sekali di sekolah. Program perpustakaan maupun program kelas diberhentikan dan juga pelayanan perpustakaan ditutup

\section{Refleksi}

Refleksi di siklus I dilaksanakan setelah diadakan penelitian sebelum sekolah ditutup. Hambatan yang muncul pada penelitian di siklus 1 ini adalah terbatasnya waktu penelitian sehingga program yang dijalankan oleh peneliti belum terlaksana semuanya. Selain itu, pihak sekolah yang bekerja sama dengan peneliti khususnya guru bahasa Indonesia sibuk dengan kegiatan sekolah yaitu persiapan perseni dan ujian sekolah peserta didik sehingga program yang direncanakan belum sempat untuk dilaksanakan. Selain itu, program tidak berjalan lancar dikarenakan sekolah fakum selama tiga bulan, dan juga pegawai perpustakaan, guru dan peserta didik melaksanakan proses belajar mengajar secara online. Pada siklus berikutnya peneliti akan mengefisienkan waktu yang ada dan juga akan membuat perencanaan yang sesuai dengan kondisi sekarang yang semua pelayanan perpustakaan berbasis online.

\section{Siklus II}

\section{Perencanaan}

Pada tahap perencanaan tindakan siklus II, peneliti bekerja sama dengan kepala perpustakaan terkait program yang sesuai dengan kondisi sekarang dimana semua berbasis online. Di masa pandemi ini peneliti menawarkan ide yakni membuat sebuah aplikasi yang bisa memudahkan peserta didik tetap menikmati koleksi perpustakaan meskipun berbasis online. Adapun perencanaan yang akan dilakukan oleh peneliti yaitu bekerja sama dengan kepala perpustakaan membuat aplikasi e-perpustakaan. 


\section{Pelaksanaan}

Agar perpustakaan tetap aktif di masa pandemi yang semua diharuskan berbasis online maka diterapkanlah e-perpustakaan, yaitu aplikasi yang bisa digunakan peserta didik untuk tetap bisa menikmati koleksi perpustakaan lewat layanan membaca. E-perpustakaan merupakan aplikasi perpustakaan digital yang menyediakan berbagai macam buku-buku dalam bentuk digital yang dapat diakses oleh peserta didik menggunakan smartphone ataupun laptop. Jadi peserta didik bisa mengakses kapan dan dimana pun buku yang diinginkan karena eperpustakaan bisa digunakan 24 jam. Peserta didik dapat membaca buku yang telah disediakan di e-perpustakaan dan peserta didik dapat mengakses dan membaca buku yang tersedia di e-perpustakaan baik itu buku pelajaran maupun buku umum yang bisa menjadi hiburan di waktu senggang.

Pertama-tama semua jenis koleksi buku, baik itu buku pelajaran maupun buku umum (fiksi dan nonfiksi) yang akan diakses oleh peserta didik dimasukkan terlebih dahulu ke Google Drive, sesudah itu di Google Drive kita hubungkan ke google sites, sesudah itu semua koleksi buku yang telah dimasukkan sudah bisa diakses oleh peserta didik. Jadi peserta didik bisa mengakses buku-buku yang telah tersedia di e-perpustakaan. Langkah selanjutnya membagikan link (https://sites.google.com/view/e-perpustakaan-mtsn-gowa/halaman-muka)

kepada peserta didik agar mereka bisa mengakses koleksi buku yang diinginkan. Sebelum mengakses buku mereka terlebih dahulu harus mengisi daftar pengunjung e-perpustakaan Madrasah Tsanawiyah Negeri Gowa meliputi nama lengkap, jenis kelamin, alamat lengkap, dan status pengunjung (umum, kepala Madrasah Tsanawiyah Negeri Gowa, guru Madrasah Tsanawiyah Negeri Gowa, Staf Madrasah Tsanawiyah Negeri Gowa, atau peserta didik Madrasah Tsanawiyah Negeri Gowa). Setelah mengisi daftar pengunjung e-perpustakaan Madrasah Tsanawiyah Negeri Gowa, pengunjung memilih tombol kirim untuk mengirim identitas dan untuk melanjutkan ke halaman selanjutnya memilih tombol "D” yang tersedia pada formulir. Selanjutnya akan terbuka halaman muka e-perpustakaan yang terdiri dari visi misi perpustakaan dan koleksi buku digital. Untuk membaca buku pengunjung memilih koleksi buku digital yang terdiri dari buku umum dan buku pelajaran. Buku umum berisi buku fiksi dan nonfiksi, sedangkan buku mata pelajaran berisi buku pelajaran kelas VII, VIII, dan IX.

\section{Observasi}

Berdasarkan hasil observasi pada siklus II ini menunjukkan adanya peningkatan jika dibandingkan dengan siklus I. Hal tersebut ditandai dengan meningkatnya jumlah pengunjung e-perpustakaan untuk menikmati layanan baca menjadi 69 orang. 


\section{Refleksi}

Hambatan yang muncul pada siklus II ini adalah kurangnya sosialisasi antara peneliti dan pihak perpustakaan dengan peserta didik terkait program baru yang dijalankan. Pihak perpustakaan hanya memberikan link eperpustakaan ke peserta didik yang mereka kenal saja dan peserta didik yang sering datang berkunjung ke perpustakaan karena sebagian dari mereka ada yang berteman WA dengan pihak perpustakaan. Dari hasil tindakan siklus II menunjukkan hasil peningkatan minat baca sebesar $9,66 \%$ atau 45 orang. Berdasarkan peningkatan tersebut maka perlu dilakukan penelitian siklus III.

\section{Siklus III}

\section{Perencanaan}

Pada tahap perencanaan tindakan di siklus III, selain bekerja sama dengan kepala perpustakaan peneliti juga bekerja sama dengan wali kelas Madrasah Tsanawiyah Negeri Gowa terkait program yang sesuai dengan kondisi sekarang yang semua berbasis online. Di tahap ini peneliti dan kepala perpustakaan akan membagikan link e-perpustakaan kepada wali kelas sehingga merekalah yang akan membagikan ke grup kelas masing-masing.

\section{Pelaksanaan}

Berhubung karena sekolah masih berbasis online maka di tahap ini tindakan yang dilakukan oleh peneliti kurang lebih sama dengan tindakan pada tahap siklus II yaitu menerapkan aplikasi e-perpustakaan agar peserta didik tetap bisa menikmati layanan baca lewat perpustakaan digital Madrasah Tsanawiyah Negeri Gowa. Akan tetapi, pada tahap pelaksanaan tindakan di siklus III ini peneliti dan kepala perpustakaan bekerja sama dengan wali kelas Madrasah Tsanawiyah Negeri Gowa untuk mempublikasikan ke peserta didik program baru perpustakaan. Kegiatan kerja sama ini diawali dengan sosialisasi dengan wali kelas yaitu dengan menginformasikan kepada semua wali kelas untuk ikut terlibat dalam program perpustakaan yang berbasis online. Kegiatan sosialisasi tersebut dilakukan di ruang guru disaat semua guru sedang berkumpul. Pada kesempatan ini peneliti dan kepala perpustakaan menyampaikan bahwa perpustakaan sudah aktif kembali dan peserta didik sudah bisa menikmati layanan baca berbasis online. Peneliti dan kepala perpustakaan juga membagikan link yang bisa diakses oleh peserta didik ketika ingin berkunjung (https://sites.google.com/view/e-perpustakaan-mtsngowa/halaman-muka).

\section{Observasi}

Berdasarkan hasil observasi pada siklus III, menunjukkan adanya peningkatan jika dibandingkan dengan siklus II. Hal tersebut ditandai dengan 
meningkatnya jumlah pengunjung e-perpustakaan untuk menikmati layanan baca menjadi 151 orang. Di siklus III ini peserta didik banyak yang berkunjung ke e-perpustakaan dikarenakan peserta didik sudah mendapatkan informasi dari wali kelas terkait program baru perpustakaan yaitu e-perpustakaan. Lewat eperpustakaan mereka tetap bisa menikmati koleksi perpustakaan tanpa harus datang ke perpustakaan.

\section{Refleksi}

Dari hasil tindakan siklus III minat baca peserta didik mengalami peningkatan, hal tersebut bisa dilihat dari jumlah pengunjung yang meningkat sebanyak 151 orang, dimana pada siklus sebelumnya hanya sebanyak 69 orang. Hasil peningkatan minat baca pada siklus III sebesar 17,59\% atau 82 orang. Berdasarkan peningkatan tersebut maka penelitian ini berhenti di siklus III.

Pada siklus I pelaksanaan program yang telah direncanakan oleh peneliti berjalan lancar akan tetapi belum ada peningkatan yang signifikan dari segi minat bacapeserta didik. Hal tersebut bisa dilihat dari jumlah pengunjung yang hanya 24 orang. Kemudian peneliti lanjut ke tahap siklus II, pada tahap ini peneliti bekerja sama dengan kepala perpustakaan untuk membuat suatu aplikasi yang bisa membuat perpustakaan tetap berjalan meskipun keadaan masih pandemi. Pada tahap siklus II jumlah pengunjung meningkat jika dibandingkan dengan siklus I yaitu sebanyak 69 orang atau dengan kata lain hasil peningkatannya sebesar 9,66\%. Hambatan yang muncul pada siklus II ini adalah kurangnya sosialisasi antara peneliti dan pihak perpustakaan dengan peserta didik terkait program baru yang dijalankan. Pihak perpustakaan hanya memberikan link e-perpustakaan ke peserta didik yang mereka kenal saja dan peserta didik yang sering datang berkunjung ke perpustakaan karena sebagian dari mereka ada yang berteman WA dengan pihak perpustakaan. Pada siklus III minat baca peserta didik Madrasah Tsanawiyah Negeri Gowa meningkat, hal ini bisa dilihat dari jumlah pengunjung sebanyak 151 orang atau dengan kata lain hasil peningkatannya sebesar 17,59\%. Dengan demikian dapat disimpulkan bahwa minat baca peserta didik di Madrasah Tsanawiyah Negeri Gowa meningkat pada siklus III.

\section{PENUTUP}

Implementasi manajemen perpustakaan dapat meningkatkan minat baca peserta didik di Madrasah Tsanawiyah Negeri Gowa. Hal ini dapat dilihat dari jumlah pengunjung perpustakaan yang semakin meningkat di setiap siklusnya yaitu pada siklus 1 sebanyak 24 orang (5,15\%), siklus II sebanyak 69 orang $(14,81 \%)$, dan siklus III sebanyak 151 orang $(32,40 \%)$ dari jumlah total peserta didik sebanyak 466 orang. Berdasarkan perhitungan tersebut, siklus 1 ke siklus II mengalami peningkatan sebesar 9,66\% sedangkan dari siklus II ke siklus III 
mengalami peningkatan sebesar 17,59\%. Dengan demikian minat baca peserta didik di Madrasah Tsanawiyah Negeri Gowa mengalami peningkatan. Implikasi dari penelitian ini yaitu kepala madrasah sebaiknya menyediakan sarana dan prasarana yang memadai di perpustakaan agar peserta didik merasa senang dan tertarik untuk masuk perpustakaan. sementara itu, pihak perpustakaan harus meningkatkan lagi manajemen perpustakaan yang baik dalam melaksanakan program kerja yang telah disusun dengan membuat SOP agar pelaksanaan setiap program kerja bisa berjalan dengan efektif dan efisien.

\section{DAFTAR PUSTAKA}

Ahmadi, F. (2010). Meningkatkan Minat Membaca Siswa SD dengan Metode Glenn Doman Berbasis Multimedia. Jurnal Penelitian Pendidikan, 27(1).

Arsyad, A. (2011). Pokok-Pokok Manajemen: Pengetahuan Praktis Bagi Pimpinan dan Eksekutif. Yogyakarta: Pustaka Pelajar.

Bistara, Y. (2016). Implementasi Manajemen Perpustakaan dalam Meningkatkan Minat Baca Peserta didik di SMA Kemala Bayangkari Kota Bumi Lampung Utara". Skripsi: Fakultas Tarbiyah Dan Keguruan, Institut Agama Islam Negeri Intan Lampung.

Danial, D., \& Damopolii, M. (2019). Hubungan antara Budaya Madrasah dengan Motivasi Kerja Guru di MTs se-Kecamatan Sinjai Barat. Lentera Pendidikan, 22(1), 141-156. https://doi.org/https://doi.org/10.24252/lp.2019v22n1i12

Enyang, S., Marlina, R., \& Khairunnisya. (2015). Implementasi Manajemen Perpustakaan Sekolah untuk Meningkatkan Minat Baca dan Hasil Belajar Siswa SMA Negeri 2 Gunung Labuhan Kabupaten Way Kanan. 1(1). Staialmaarifwaykanan. Ac. Idindex. Php/jah/articelview24/19

Getteng, A. R. (2014). Menuju Guru Profesional dan Ber-Etika. Yogyakarta: Graha Guru.

Hartono. (2016). Management Perpustakaan Sekolah. Yogyakarta: Ar-Ruzz Media.

Juni, T. W. (2016). Bangkit dengan Membaca. Makassar: Ikatan Pustakawan Indonesia Provinsi Sulawesi Selatan.

Kalida, M. (2015). Capacity Building Perpustakaan. Yogyakarta: Aswaja Pressindo.

Lubis, S. (2019). Nilai Pendidikan pada Surah Al-'Alaq Ayat 1-5 Menurut Quraish Shihab. Jurnal Ilmiah Al-Hadi, 4(2). http://jurnal.pancabudi.ac.id/index.php/ alhadi/article/view/745

Maharani, O. D., \& et al. (2017). Minat Baca Anak-Anak Di Kampoeng Baca Kabupaten Jember. Jurnal Review Pendidikan Dasar: Jurnal Kajian Pendidikan Dan Hasil Penelitian, 3(1). http://journal.unesa.ac.id.index/php/PD

Rahman, D. (2021). Pemanfaatan Internet Sebagai Sumber Belajar dan Informasi. Jurnal Perpustakaan Dan Informasi, 1(1), 9-14.

RI, D. A. (2012). Al-Qur'an dan Terjemahnya. Jakarta: Insan Media Pustaka. 
Sagala, S. (2014). Administrasi Pendidikan Kontemporer. Bandung: Alfabeta.

Suwarno, W. (2011). Perpustakaan dan Buku: Wacana Penulisan dan Penerbitan. Jogjakarta: Ar-Ruzz Media.

Toha, M. (2015). Pengelolaan Perpustakaan dalam Meningkatkan Minat Baca Siswa pada mata pelajaran Pendidikan Agama Islam di MTs Negeri Tulungagung dan MTs As-Syafi'iyah Gondang. Tesis: Pascasarjana IAIN Tulungagung.

Wahyuningsih, T. (2011). Pengelolaan Perpustakaan Sekolah Dasar di Kecamatan Sragen Studi Situs SD Negeri Sragen 4 SD Birrul Walidain. Tesis: Pascasarjana Universitas Muhammadiyah Surakarta.

Yaumi, M., \& Damopolii, M. (2014). Action Research Teori, Model, dan Aplikasi. Jakarta: Kencana.

Yeni, F. (2020). Strategi Manajemen Perpustakaan Sekolah dalam Upaya Peningkatan Minat Baca Siswa di MA Nahdlatul Ulama Kraksaan Probolinggo. Masters Thesis: Institut Pesantren Kh. Abdul Chalim. 